\title{
Effect of Calcium (Hardness of Water) on The Uptake of Ciprofloxacin in Bath-Medicated African Catfish (Clarias Gariepinus)
}

\author{
*OLADELE, O.O'. OlUfemi, B.E. ${ }^{2}$, AGBATO, O. A. ${ }^{1}$, JIBIKE, G $^{3}$. and ADESIYAN, F. A4.
}

\footnotetext{
Poultry and Fish Diseases Diagnostic Lab, Animal Care Services Konsult(Nig.) Itd, Ogere Remo, Ogun state. ${ }^{2}$ Dept. of Veterinary Medicine, Faculty of Vet.Medicine,University of Ibadan, Ibadan, Nigeria. ${ }^{3}$ Department of Vet.Physiology and Pharmacology, Faculty of Vet. Medicine, University of Maiduguri, Borno state, Nigeria. ${ }^{4}$ Diosecan Agric. Development Programme, JDPC, ljebu-ode, Ogun State. *Corresponding Author E mail :_vetmand07@yahoo.com
}

\section{SUMMARY}

Seventy -two catfishes weighing between 200 and $250 \mathrm{~g}$ (and distributed into 3 groups) were subjected to bath medication with ciprofloxacin at $25 \mathrm{mg} /$ litre of water. Medicated water of each group (24 catfishes/group) had the same $\mathrm{pH}$ of 6.6, after adjustment using sodium carbonate, but different levels of calcium hardness Group A water had $12.5 \mathrm{mg} /$ litre of calcium hardness, while for groups $B$ and $C$, the levels of the calcium hardness were adjusted to $212.5 \mathrm{mg} /$ litre and $412.5 \mathrm{mg} /$ litre respectively using calcium chloride. Samples (blood, liver, kidney and muscle) were taken from two randomly selected fishes in each group within 8 hours of exposure to ciprofloxacin. These were taken at 0 $h, 0.5 h, 1 h, 2 h, 4 h$, and $8 \mathrm{~h}$ and were preserved at $0.5 \square$ C, prior to processing and drug extraction. Ciprofloxacin level was quantified by ELISA. The sera area under the curve (AUC) values of groups $A, B$ and $C$ were 17,938.13 $\mathrm{\mu g} . \mathrm{hr} . / \mathrm{L}, 18,883.75 \mathrm{\mu g} . \mathrm{hr} . / \mathrm{L}$ and $12,273.75 \mu \mathrm{g} . \mathrm{hr}$./L respectively, showing that at the highest concentration of calcium ions in medicated water (as seen in group c ) level of the absorption of ciprofloxacin will be reduced, hence reduced bioavailability There was also a direct linear relationship between the AUC values for tissue and the level of calcium hardness of water. This study therefore suggests a need to strongly consider the influence of core chemical parameters of fish culture water such as hardness, alkalinity and pH, as these can reduce efficacy or increase toxicity of drugs that are administered to fish by bath method.

Keywords: Catfish, Ciprofloxacin, ELISA, hard (calcium) water.

\section{INTRODUCTION}

In Nigeria, the African catfish (Clarias gariepinus) is of high economic and nutritional value and is about the most cultured freshwater fish (AIFP, 2004). With the apparent increase in culture of fish, the production pressure appears to give way to susceptibility to infectious diseases which can have devastating effect on the finances of fish farmers if they are not properly and promptly diagnosed and treated. In fish medication, bath administration of antibiotics often becomes the best alternative and starting point when anorexia becomes prominent in a bacterial disease outbreak. Bath treatment offers an equal dose to both healthy and diseased fish and is easy to carry out with agents of sufficient water solubility. It has also been found to be a good alternative in treatment of small fish at the hatchery (Samuelsen and Lunstad, 1996). The efficacy, safety or toxicity of drugs used in fish medication by bath are however strongly influenced by the chemical and physical parameters of water such as $\mathrm{pH}$, alkalinity, temperature and total hardness (sum of calcium and magnesium salts).

Ciprofloxacin which was used in this study is a fluoroquinolone and a metabolite of Enrofloxacin. It is an antimicrobial of choice in many bacterial disease conditions in man and animals. Nouws et al. (1988) also demonstrated its pharmacokinetics in carp, catfish and rainbow trout. Ciprofloxacin acts by inhibition of bacterial DNA gyrase (Booth, 1998). This drug, like other quinolones is known to interact with 
divalent cations like $\mathrm{Ca}^{2+}$ and $\mathrm{Mg}^{2+}$ by chelating them and resulting in reduced bioavailability of the drug by reduction in uptake or absorption in broilers (Sunamo et al., 2004) and in man (Kato et al., 2002).

This study investigated the effect of graded levels of calcium hardness in water on the uptake of ciprofloxacin in bath medicated African catfish at $25 \mathrm{mg}$ ciprofloxacin per litre of water, over a period of 8 hours. This bath concentration of ciprofloxacin had earlier been shown to produce significant sera and tissue levels in Clarias gariepinus in comparism with a higher bath concentration of $50 \mathrm{mg}$ ciprofloxacin/litre of water (Oladele, 2008).

\section{MATERIALS AND METHODS}

A total of 72 catfishes (Clarias gariepinus) weighing between 200 and $250 \mathrm{~g}$ were stocked in 6 plastic tanks, each of 80 litres capacity, after adjusting the water chemistry for each group. Each tank was filled with water up to the 60 litres mark and 12 catfishes, hence 24 catfishes in 2 tanks, made a group.

In groups $\mathrm{A}, \mathrm{B}$ and $\mathrm{C}$, the $\mathrm{pH}$ of the water was adjusted from 5.6 to 6.6 by adding 1.8 gm of sodium carbonate to every 60 litres of water. Group A which had only the $\mathrm{pH}$ being adjusted, had a calcium hardness level of $12.5 \mathrm{ppm}$ (mg/litre). This was determined by titrating $0.01 \mathrm{~N}$ of EDTA (ethylene diamine tetraacetic acid) into a mixture of $20 \mathrm{ml}$ of water sample and $5 \mathrm{ml}$ of $1 \mathrm{~N} \mathrm{NaOH}$ solution with murexide indicator to obtain an endpoint (from pink to violet). Calculations to arrive at level of calcium hardness were done as described by Chattopadhyay, (1998). Groups B and C had their calcium hardness adjusted to 212.5 $\mathrm{mg} /$ litre and $412.5 \mathrm{mg} / \mathrm{l}$ by adding calcium chloride at the rate of 24 gms/ 60 litres and 48 gms/60 litres, respectively. Group A water which was not treated with calcium chloride was soft water, while groups B and C water were hard and very hard, respectively.

Samples were taken before and during the drug administration. The administered drug was thoroughly mixed with water containing the catfish. The drug, Ciprotril ${ }^{\circledast}$, $10 \%$ ciprofloxacin, manufactured by Veterinary and Agricultural Products Manufacturing Company Limited, Jordan, was used.

Catfish were subjected to a bath treatment, using $10 \%$ ciprofloxacin at a rate of $1 \mathrm{ml}$ (100mg) per 4 litres of water for 8 hours. This gave a final concentration of $25 \mathrm{mg}$ ciprofloxacin/ litre of water.

Before blood collection, the peduncle of each fish was thoroughly mopped, using tissue paper to remove slime and drops of medicated water on the region. The caudal portion (about 2 inches away from the tail) was transected, using a pair of sharp scissors, and the jet of blood from the caudal vein was captured into an Eppendorf tube and labeled appropriately.

The same fish was further restrained, to transect the spinal cord in order to prevent strong muscular contractions, hence making it easier to handle. The fish was then placed on its dorsum to make incision into the abdominal cavity. Samples were excised from the liver and the kidney. Portions of muscles from the incised abdominal wall were also taken and all were labeled according to the groups and time taken.

All samples were preserved at $-0.5^{\circ} \mathrm{C}$ to $+4^{\circ} \mathrm{C}$ in a compartment of a refrigerator before the drug extraction and quantification since extraction soon followed sample collection. Blood samples collected in Eppendorf tubes were spinned using a centrifuge (Haraeus Biofuge Primo Centrifuge Thermo Electron Corporation, Germany) at 10,000 rpm for 10 minutes, to separate out the sera. The sera were aspirated using new pipette tips for each and dispense in new Eppendorf tubes and relabeled before preservation at $0.5^{\circ} \mathrm{C}$.

Liver, kidney and muscle were pooled together at each time interval from each of the two catfish taken from each group and were labeled accordingly. For example, Group A had the Muscle ${ }_{\mathrm{A} 1}$ and Muscle $_{\mathrm{A} 2}$ at 2hours intra medication, pooled together as one sample for 'Group A Muscle (2 h)'. 
Similar thing was done for the liver and the kidney samples for each group and time interval. Serum samples were not pooled.

Blood, liver, kidney and skeletal muscle samples were collected at 0 hour (before drug administration) $0.5 \mathrm{~h}, 1 \mathrm{~h}, 2 \mathrm{~h}, 4 \mathrm{~h}$ and $8 \mathrm{~h}$ (intra drug administration) from the randomly selected fish. A pair of scissors was used in separating the skin from the muscle samples.

Routine cleaning of used portions (hollow portion) of improvised plastic container was done, using $70 \%$ methanol, in order to prevent any cross contamination. Each macerated samples was weighed, using a digital precision balance (Contech Instruments Company, Mumbai, India). A gram of tissue was weighed and $4 \mathrm{ml}$ of $70 \%$ methanol was added $(99.8 \%$ methanol from FLUKA, was diluted to $70 \%$ using the formula $\mathrm{C}_{1} \mathrm{~V}_{1}=\mathrm{C}_{2} \mathrm{~V}_{2}$. The extract was thus a 1:5 dilution of original concentration of the drug in the tissue of this dilution, $15 \mu \mathrm{l}$ was taken and further diluted in $585 \mu \mathrm{l}$ of $70 \%$ methanol $(15: 600=1: 40$ dilution), thus increasing the dilution to 1: 200 (1:5X40). Therefore, the results of optical density reading of tissue samples, when extrapolated on the standard curve to obtain the corresponding concentrations, needed to be multiplied by a factor of 200 to obtain the exact concentration of ciprofloxacin, therein. The sera were diluted to obtain a dilution of $1: 150$ ( $4 \mu \mathrm{l}$ of serum to $596 \mu \mathrm{l}$ of $70 \%$ methanol $=4: 600=1: 150$ ) .

All further dilutions were done in plastic dilution tubes which were vertically positioned in wells of old microtitre plates. All dilutions were thoroughly and individually mixed using an Eppendorf ${ }^{\circledR}$ multichannel pipette fitted with pipette tips. Fifty (50) $\mu$ l of each diluted sample was used in the assay. These further dilutions were done to ensure that optical densities of samples fall within the 0 to $81 \mathrm{ppb}(\mu \mathrm{g} / \mathrm{kg}$ or $\mu \mathrm{l} /$ litre) range of standards of Ciprofloxacin, before multiplication by dilution factors.

The values of $\mathrm{AUC}_{(0-\text {-shrs) }}$, that is area under the curve for sera of groups A, B and C were calculated by trapezoidal method as described by Riviere(1999). The Ridasreen ${ }^{\circledR}$ Enro/Cipro ELISA kit from R-Biopharm AG, Darmstadt, Germany, designed for quantifying enrofloxacin or ciprofloxacin residues in edible tissue(pork, fish, beef and shrimps) was adapted for studying absorption and organ distribution of ciprofloxacin in catfish.

\section{RESULTS}

The outcome of the levels of ciprofloxacin in sera and tissues (liver, kidney and skeletal muscle) of different groups of Clarias gariepinus subjected to same bath concentration of ciprofloxacin ( $25 \mathrm{mg} /$ litre), but different levels of calcium hardness are as shown in tables I to III.

There was a rapid absorption of ciprofloxacin within the first 30 minutes of exposure in all groups of fish. Peak concentration of the $\operatorname{drug}\left(\mathrm{C}_{\max }\right)$ in sera of group A catfishes was $2396.25 \mu \mathrm{g} / \mathrm{L}$ (ppb) at the $8^{\text {th }}$ hour of exposure, while in groups B and C sera, the $\mathrm{C}_{\max }(2827.5 \mu \mathrm{g} / \mathrm{L}$ and 2265 $\mu \mathrm{g} / \mathrm{L}$ respectively) were observed at the $4^{\text {th }}$ and $1^{\text {st }}$ hour of bath treatment as shown on tables I, II and III. Generally the kidneys appear to have the highest concentration of the drug, followed by liver and skeletal muscle. This pattern appears to be the same in all groups and at all the time intervals when samples were taken.

From the result in tables I, II and III, there appeared to be a gradual and steady decline in uptake /absorption of ciprofloxacin between the $2^{\text {nd }}$ and $8^{\text {th }}$ hours in group $\mathrm{C}$ fish exposed to the highest concentration of $\mathrm{Ca}^{2+}(412.5 \mathrm{mg} /$ litre calcium hardness), whereas in group A (soft water) with $12.5 \mathrm{mg} /$ litre of calcium hardness ,there was a gradual increase in the uptake of ciprofloxacin between the $2^{\text {nd }}$ and the $8^{\text {th }}$ hours post exposure. In group B, between the $2^{\text {nd }}$ and $8^{\text {th }}$ hours, there was an initial rise $\left(2^{\text {nd }}\right.$ to $4^{\text {th }}$ hour) but a decline between the $4^{\text {th }}$ and 8 th hour post exposure to ciprofloxacin.

The AUC (area under the curve) values as shown on table IV for the sera group is a reflection of the degree of absorption of the 
drug from the water, into the blood of the catfishes through the gills. The AUC (0.8h) values of tissues (liver, kidney and muscle) for each of the groups are shown in table IV). These values reflect the level of drug movement from the blood into tissues (distribution), under different condition of hardness over a period of 8 hours. The ratio of the organ AUC to sera AUC are as shown in table $\mathrm{V}$. In group $\mathrm{A}, \mathrm{Lv} / \mathrm{S}$ (liver to sera), $\mathrm{Kd} / \mathrm{S}$ (kidney to sera) and Ms/S(muscle to sera) AUC ratios were 1.69, 1.78 and 0.86 respectively. In group $B$, they were 1.285 , 1.45 and 0.62 (respectively), while for group C they were 1.4, 1.77 and 0.77 (respectively), under the highest concentration of $\mathrm{Ca}^{2+}$.

Table I: GROUP A: Ciprofloxacin concentration in sera and tissues of catfish in water with $12.5 \mathrm{mg} / \mathrm{l} \mathrm{of}$ calcium hardness, within $8 \mathrm{~h}$ exposure time

\begin{tabular}{|llllc|}
\hline Time (Hours) & Serum $(\mu \mathrm{g} / \mathrm{L})$ & Liver $(\mu \mathrm{gg} / \mathrm{Kg})$ & Kidney $(\mu \mathrm{g} / \mathrm{Kg})$ & Muscle $(\mu \mathrm{g} / \mathrm{Kg})$ \\
\hline 0 & 0.00 & 0.00 & 0.00 & 0.00 \\
0.5 & $1665+170.45$ & 3440 & 2460 & 1880 \\
1 & $2542.5+102.6$ & 2100 & 2840 & 1520 \\
2 & $2212.5+472.5$ & 3240 & 2640 & 1860 \\
4 & $2362.5+208.19$ & 5000 & 5120 & 1780 \\
8 & $2396.25+155.81$ & 4100 & 4660 & 2640 \\
\hline
\end{tabular}

Table II: GROUP B-Ciprofloxacin concentration in sera and tissues of catfish in water with $212.5 \mathrm{mg} / \mathrm{lof}$ calcium hardness, within $8 \mathrm{~h}$ exposure time.

\begin{tabular}{|lllll|}
\hline Time (Hours) & Serum $(\mu \mathrm{g} / \mathrm{L})$ & Liver $(\mu \mathrm{g} / \mathrm{Kg})$ & Kidney $(\mu \mathrm{g} / \mathrm{Kg})$ & Muscle $(\mu \mathrm{g} / \mathrm{Kg})$ \\
\hline 0 & 0.00 & 0.00 & 0.00 & 0.00 \\
0.5 & $2666.25+36.52$ & 2640 & 2400 & 1440 \\
1 & $1365+405.5$ & 1930 & 1700 & 1360 \\
2 & $2602.5+528.81$ & 2860 & 3760 & 1540 \\
4 & $2827.5+9.86$ & 3120 & 3300 & 1040 \\
8 & $2136+15.05$ & 3920 & 4660 & 2100 \\
\hline
\end{tabular}

Table III: Group C- Ciprofloxacin concentration in sera and tissues of catfish in water with $412.5 \mathrm{mg} / \mathrm{l} \mathrm{of}$ calcium hardness, within $8 \mathrm{~h}$ exposure time.

\begin{tabular}{|lllll|}
\hline Time (Hours) & Serum $(\mu \mathrm{g} / \mathrm{L})$ & Liver $(\mu \mathrm{g} / \mathrm{Kg})$ & Kidney $(\mu \mathrm{g} / \mathrm{Kg})$ & Muscle $(\mu \mathrm{g} / \mathrm{Kg})$ \\
\hline 0 & 0.00 & 0.00 & 0.00 & 0.00 \\
0.5 & $1462.5+41.35$ & 1640 & 1640 & 1260 \\
1 & $2265+240.97$ & 1900 & 3100 & 1720 \\
2 & $2212.5+38.03$ & 2640 & 2300 & 1400 \\
4 & $1365+31.87$ & 1520 & 3120 & 660 \\
8 & $1215+76.52$ & 3220 & 2860 & 1740 \\
\hline
\end{tabular}

Table IV: AUC (0-8 HRS) values of ciprofloxacin for groups A, B and C sera and tissues of catfishes in water with calcium hardness of $12.5 \mathrm{mg} / 1,212.5 \mathrm{mg} / \mathrm{l}$ and $412.5 \mathrm{mg} / \mathrm{l}$, respectively.

\begin{tabular}{|l|cccc|}
\hline & SERUM $(\mu \mathrm{g} \cdot \mathrm{hr} . \mathrm{L}-1)$ & LIVER $(\mu \mathrm{g} \cdot \mathrm{hr} . \mathrm{Kg}-1)$ & $\mathrm{KIDNEY}(\mu \mathrm{g} \cdot \mathrm{hr} \cdot \mathrm{Kg}-1)$ & MUSCLE $(\mu \mathrm{g} \cdot \mathrm{hr} . \mathrm{Kg}-1)$ \\
\hline GROUPA & $17,938.13$ & 30,410 & 32,000 & 15,490 \\
GROUPB & $18,883.75$ & $24,257.5$ & 27,335 & 11,370 \\
GROUPC & $12,273.75$ & 17,205 & 21,675 & 9,480 \\
\hline
\end{tabular}


Table V: Tissue /serum AUC ratio of ciprofloxacin for groups A, B and C catfishes in water with calcium hardness of $12.5 \mathrm{mg} / \mathrm{l}, 212.5 \mathrm{mg} / \mathrm{l}$ and $412.5 \mathrm{mg} / \mathrm{l}$, respectively.

\begin{tabular}{|clll|}
\hline GROUPS & LIVER/SERUM & KIDNEY/SERUM & MUSCLE/SERUM \\
\hline A & 1.69 & 1.78 & 0.86 \\
B & 1.285 & 1.45 & 0.62 \\
C & 1.4 & 1.77 & 0.77 \\
\hline
\end{tabular}

\section{DISCUSSION}

The pattern of reduction in uptake of ciprofloxacin in fish with increasing concentration of $\mathrm{Ca}^{2+}$ in medicated water as observed in this study, appears to be in agreement with findings of O'Grady et al., (1988) who studied the uptake of flumequine (a fluoroquinolone) in brown trout immersed in various drug concentrations, temperature, water hardness and $\mathrm{pH}$.

Despite the difference of $200 \mathrm{mg} /$ litre of calcium hardness between water for groups A $(12.5 \mathrm{mg} / \mathrm{l})$ and B $(212.5 \mathrm{mg} / \mathrm{l})$, there appears to be no major difference in the sera AUC values $\left(17,938.13 \mu \mathrm{g} . \mathrm{hr} . \mathrm{L}^{-1}\right.$ and 18,883.75 $\mu \mathrm{g} \cdot \mathrm{hr} . \mathrm{L}^{-1}$, respectively). However in group C with $412.5 \mathrm{mg} / 1$ calcium hardness, there was a sharp drop in the sera AUC value $\left(12,273.75 \mu \mathrm{g} \cdot \mathrm{hr} \cdot \mathrm{L}^{-1}\right)$. This observation in group $\mathrm{C}$ clearly shows that at $412.5 \mathrm{mg} / \mathrm{L}$ of calcium hardness, ciprofloxacin absorption into the blood stream in the African catfish was reduced. This is of clinical importance, especially in the control of bacteraemic conditions in fish. Under this condition of exposure to very hard water; it may be difficult for the fish to attain serum levels of ciprofloxacin, similar to and above the MIC of ciprofloxacin against the target bacterium.

A failure in therapy would ensue as shown by the observation of Hiney et al.(1995) who found major differences in the flumequine pharmacokinetics between Atlantic salmon in fresh water and in sea water ,because of complexing of flumequine with divalent cations in sea water .This may be why the dosing of oxolinic acid (another quinolone used in fish medicine) in freshwater fish species is lower $(10 \mathrm{mg} / \mathrm{kg} /$ day) than in marine species( $25-$
$50 \mathrm{mg} / \mathrm{kg}$ /day) (Treves-Brown, 2000).

The level of the ciprofloxacin appears to be highest in kidneys, followed by liver and skeletal muscles being the least. This agrees with the pattern of oxolinic acid in fish (Jacobsen, 1989). The muscle having the lowest level of ciprofloxacin is quite expected, since it is the least vascularized amongst these organs.

The implication is that under disease conditions involving deep muscle tissue as seen in emphysematous putrefactive disease of catfish (caused by Edwardsiella tarda), or furunculosis, the option needed to arrive at and maintain sufficient therapeutic level would involve either increasing the drug concentration and/or increasing the exposure time to the drug, where reduction in water hardness is not feasible.

Note that in group $\mathrm{C}$ at the $4^{\text {th }}$ hour, the concentration of ciprofloxacin in the muscles, dropped to $660 \mu \mathrm{g} / \mathrm{kg}$ which is below $1000 \mu \mathrm{g} / \mathrm{L}$ or $\mu \mathrm{g} / \mathrm{kg}$ ciprofloxacin concentration which is considered the average $\mathrm{MIC}_{50}$ value of ciprofloxin for most fish pathogenic bacterial isolates by Kirkan et al. (2006). They further showed that MIC range for ciprofloxacin against Enterococcus seriolicida was $0.13-4 \mathrm{mg} / 1$ (130-4000 $\mu \mathrm{g} / \mathrm{l})$. It was only in groups A and B liver and kidney samples that some tissue levels of ciprofloxacin were found to be above the upper limit of the range. Comparism of the ratio of AUC values of each organ to sera in each group (as shown in table V) revealed within each group, a decrease from kidney to liver and muscle. However for each organ a comparison of tissue ratio showed an initial decrease from group A to B (eg 1.69 to1.285 for group A and B Lv /s AUC ratio) and a rise in value between group $B$ and $C$ (1.285 to 1.4). It appears there is an attempt 
to re-establish the ratio as was initially seen in group A. This may reflect a homeostastic response, even though overall drug absorption and distribution appears to be on the decline at exposure to high $\mathrm{Ca}^{2+}$ level (412.5ppm).

In fish disease management, bath medication becomes an unavoidable method of administering antibiotics when anorexia becomes a prominent feature in bacterial disease outbreak, especially when dealing with large number of sick fishes that would be too many to inject. Despite the advantage that bath medication may have under anorexic condition of sick fishes, it is still very important to take into consideration, the design and peculiarities of the fish culture system in use, apart from the core chemical parameters of pond water. This will help prevent errors in medication and reduce cost of treatment.

\section{REFERENCES}

AQUACULTURE AND INLAND FISHERIES PROJECT (AIFP), (2004): 'Inventory of fish farms in Nigeria'-FAO and Federal government of Nigeria joint project on National special programme on food security: pp 1-148.

BOOTH, D.M.(1998): 'Antibacterial agents' in Merck Veterinary manual $\left(8^{\text {th }}\right.$ edition), Merck and Co. Inc. p1762.

CHATTOPADHYAY, G.N.(1998): Chemical analysis of fish pond and water. Daya Publishing House, India. Pp 36-39.

HINEY, M.P., COYNE, R., KERRY, J., PURSELL, L., SAMUELSEN, O.B. AND SMITH, P. (1995): Failure of Flumisol ${ }^{\circledR}$ bath treatments during commercial transport of Atlantic Salmon smolts to prevent activation of stress inducible furunculosis. Aquaculture, 136: 31-42.

JACOBSEN, M.D.(1989): Withdrawal times of freshwater rainbow trout, Salmo gairdneri Richardson, after treatment with oxolonic acid, oxytetracycline and trimethoprim. J Fish Dis., 12, 29-36.

KATO, R., UENO, K., IMANO, H., KAWAI, M., KUWAHARA, S., TSUCHISHISTA, Y., YONEZAWA, E.AND TANAKA, K.
(2002): Impairment of ciprofloxacin absorption by calcium polycarbophil. J Clin Pharmacol, 42: 806-811.

KIRKAN, S., GOKSOY, E.O., KAYA, O. AND TEKBIYIK, S. (2006): In-vitro antimicrobial susceptibility of pathogenic bacteria in Rainbow trout (Oncorhynchus mykiss, Walbaum). Turk. J. Vet. Anim. Sci. 30: 337-341.

NOUWS, J.F; GRONDEL, J.L.; SCHUTTE, A.R. AND LAURENSEN, J.(1988): Pharmacokinetics of ciprofloxacin in Carp, African catfish and Rainbow trout. Vet Q., 10(3):211-216

O'GRADY, P., MOLONEY, M. AND SMITH, P.R.(1988): Bath administration of the quinolone antibiotic flumequine, to brown trout Salmo trutta L. and Atlantic salmon Salmo salar L. Dis Aquatic Organisms, 4: 27-33.

OLADELE, O. O. (2008): Pharmacokinetics of ciprofloxacin in Clarias gariepinus (By ELISA), post-bath treatment at different concentrations. MVSc dissertation, University of Ibadan, Nigeria. p36.

RIVIERE, J. E. (1999): 'The Trapezoidal method for estimating Areas under curve' in Comparative pharmacokinetics: principles, techniques and applications. Iowa State University Press, Iowa, USA. pp152153.

SAMUELSEN, O.B. AND LUNESTAD, B.T. (1996): Bath treatment, an alternative method for administration of the quinolones flumequine and oxolinic acid, to halibut (Hippoglossus hippoglossus) and in vitro activities of the drugs against some Vibrio sp. Dis Aquatic Organisms, 27:13-18.

SUMANO, L.H., GUTIERREZ, O.L., AGUILERA, R., ROSILES, M. R., BERNARD, B.M.J. AND GRACIA, M.J.(2004): Influence of hardwater on the bioavailability of Enrofloxacin in broilers. Poultry Sci., 83:726-731.

TREVES-BROWN, K.M.(2000): 'Quinolones and fluoroquinolones'. In: Applied Fish Pharmacology. Kluwer Academic Publishers. 123p. 